Had Bureau of Sindarts

Lthray, K. W. But.

AUG 131948
Reference book not to be taken from the Library.

\title{
Properties of Some
}

Lightweight-Aggregate Concretes

With and Without an

Air-Entraining Admixture

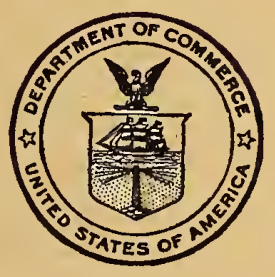

Building Materials and Structures Report BMS112

United States Department of Commerce National Bureau of Standards 


\section{BUILDING MATERIALS AND STRUCTURES REPORTS}

On request, the Superintendent of Documents, U. S. Government Printing Office, Washington 25 , D. C., will place your name on a special mailing list to receive notices of new reports in this series as soon as they are issued. There will be no charge for receiving such notices.

An alternative method is to deposit with the Superintendent of Documents the sum of $\$ 5$, with the request that the reports be sent to you as soon as issued, and that the cost thereof be charged against your deposit. This will provide for the mailing of the publications without delay. You will be notified when the amount of your deposit has become exhausted.

If 100 copies or more of any report are ordered at one time, a discount of 25 percent is allowed. Send all orders and remittances to the Superintendent of Documents, $U$. S. Government Printing Office, Washington $25, D$. $C$.

The following publications in this series are available by purchase from the Superintendent of Documents at the prices indicated:

BMS1

BMS2

BMS3

BMS4

BMS5

BMS6

BMS7

BMS8

BMS9

BMS10

BMS11

BMS12

BMS13

BMS14

BMS15

BMS16

BMS17

Supplement Supplem

BMS19

BMS20

BMS21

BMS22

BMS23

BMS24

BMS25

BMS26

BMS27

BMS28

BMS29

BMS30

BMS31

-Out of print.
Research on Building Materials and Structures for Use in Low-Cost Housing . Methods of Determining the Structural Properties of Low-Cost House Constructions_- 10\% Suitability of Fiber Insulating Lath as a Plaster Base Accelerated Aging of Fiber Building Boards Structural Properties of Six Masonry Wall Constructions

Survey of Roofing Materials in the Southeastern States.

Water Permeability of Masonry Walls

Methods of Investigation of Surface Treatment for Corrosion Protection of Steel

Structural Properties of the Insulated Steel Construction Co.'s "Frameless-Steel" Constructions for Walls, Partitions, Floors, and Roofs

Structural Properties of One of the "Keystone Beam Steel Floor" Constructions Sponsored by the H. H. Robertson Co

Structural Properties of the Curren Fabrihome Corporation's "Fabrihome" Constructions for Walls and Partitions...........

Structural Properties of "Steelox" Constructions for Walls, Partitions, Floors, and Roofs Sponsored by Steel Buildings, Inc

Properties of Some Fiber Building Boards of Current Manufacture.

Indentation and Recovery of Low-Cost Floor Coverings

Structural Properties of "Wheeling Long-Span Steel Floor" Construction Sponsored

by the Wheeling Corrugating Co Structural Properties of a "Tilecrete" Floor Construction Sponsored by Tilecrete

Floors, Inc.
Sound Insulation of Wall and Floor Constructions

nt to BMS17, Sound Insulation of Wall and Floor Constructions Structural Properties of "Pre-fab" Constructions for Walls, Partitions, and Floors Sponsored by the Harnischfeger Corporation.-.

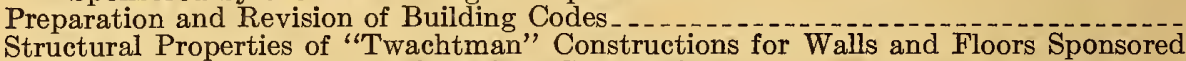
by Connecticut Pre-Cast Buildings Corporation

Structural Properties of a Concrete-Block Cavity-Wall Construction Sponsored by the

National Concrete Masonry Association
Structural Properties of "Dun-Ti-Stone" Wall Construction Sponsored by the W. E. Dunn Manufacturing Co

Manufacturers Association of New York, Inc
Structural Properties of a Reinforced-Brick Wall Construction and a Brick-Tile

Cavity-Wall Construction Sponsored by the Structural Clay Products Institute.-
Structural Properties of Conventional Wood-Frame Constructions for Walls, Partitions, Floors, and Roofs "Nelson Pre-Cast Concrete Foundation" Wall Construction Sponsored by the Nelson Cement Stone Co., Inc

Structural Properties of "Bender Steel Home" Wall Construction Sponsored by the Bender Body Co

Backflow Prevention in Over-Rim Water Supplies.

Survey of Roofing Materials in the Northwestern States.

Structural Properties of a Wood-Frame Wall Construction Sponsored by the Douglas Fir Plywood Association.

Structural Properties of "Insulite" "Wall and "Insulite" Partition Constructions Sponsored by The Insulite Co... 


\title{
Properties of Some Lightweight-Aggregate Concretes With and Without an Air-Entraining Admixture
}

\author{
by Perry H. Petersen
}

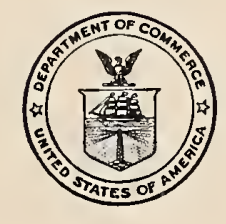

Building Materials and Structures Report BMS112 Issued August 16, 1948

For sale by the Superintendent of Documents, U. S. Government Printing Office, Washington 25, D. C. Price 10 cents 


\section{Foreword}

This report describes an investigation of the physical properties of several lightweight-aggregate portland cement concretes made with burned shale or expanded slag, undertaken in cooperation with the Federal Public Housing Authority to determine the application of such a concrete in the construction of housing.

The technical facts presented provide data from which architects and engineers can determine whether performance requirements are met.

E. U. Condon, Director. 


\title{
Properties of Some Lightweight-Aggregate Concretes With and Without an Air-Entraining Admixture
}

\author{
by Perry H. Petersen
}

\begin{abstract}
The physical properties of several lightweight aggregate portland cement concretes made with burned shale or expanded slag were investigated at the National Bureau of Standards. Three grades of concrete using each aggregate were made. Air-entrainment of greater than 20 percent is reported for the mixtures lcanest in cement, an air-cntraining admixture being used to increase the workability of all but the richest concretes. Compressive, transverse, and bond strengths are given as well as resistance to heat transfer, rain penctration, and water penetration by capillarity. Also included are the coefficients of thermal expansion, shrinkage, and values for change in length due to wetting and drying.
\end{abstract}

\section{CONTENTS}

Foreword . .

I. Introduction

II. Materials

III. Concrete $\ldots \ldots \ldots \ldots \ldots \ldots \ldots$

IV. Description of specimens and test results

1. Compressive strength

2. Flexural strength

3. Bond strength to reinforcement

4. Heat-transfer properties

(a) Shielded hot-box tests

(b) Guarded hot-plate tests_._.

(c) Results of heat-transfer tests

5. Thermal-expansion cocficients

6. Shrinkage_..... 6

7. Rain penetration

V. Summary

\section{Introduction}

The purpose of an investigation conducted at the National Bureau of Standards was to determine the physical properties of several lightweightaggregate concretes in anticipation of their use in the monolithic construction of buildings. These lightweight aggregates of burned shale or expanded slag incorporate features that tend to improve heat insulation more than the aggregates used for dense concrete. However, if the cement content is low ( 3 sacks $\left./ \mathrm{yd}^{3}\right)$, workability is so poor that placement of the concrete is extremely difficult. In- stead of flowing into the forms, the mixture is harsh and the mixing water tends to settle, taking some cement with it. This fault may be overcome by entraining air in the concrete through the use of an admixture, the entrained air totaling 20 to 25 percent by volume. When the cement content is increased to 10 or $11 \mathrm{sacks} / \mathrm{yd}^{3}$ of concrete, there is no need for entraining air to increase workability.

For tests described in this report, burned shale and expanded slag were each used as aggregates in three grades of concrete ranging upward from a 
strength of $500 \mathrm{lb} / \mathrm{in}^{2}$. An air-entraining agent was added to the two leanest mixtures for each aggregate but was omitted in the concretes which were richest in cement.

The properties covered in this investigation include compressive, transverse, and bond strengths, resistance to heat transfer, water penetration by capillarity and rain penetration. Values were determined also for shrinkage, for the coefficients of thermal expansion, and for changes in length due to wetting and drying.

\section{Materials}

The cement was a portland cement conforming to the requirements of Federal Specification SS-C191b Amendment 1.

The burned shale was a lightweight cellular aggregate made by burning a certain clay and shale to incipient fusion. The material was obtained in two sizes, coarse and fine. The sieve analyses, absorptions (surface dry), bulk specific gravities, and the weights per cubic foot of dry material are given in table 1 .

The expanded slag was a lightweight cellular aggregate made from molten hot slag as it comes from the blast furnace by agitating and cooling it rapidly in an atmosphere of steam. This material also was furnished in two sizes, coarse and fine. The physical properties are given in table 1 .

The air-entraining admixture was a commercial product made expressly for entraining air in concrete.
TABLE 1. Data on aggregates

\begin{tabular}{|c|c|c|c|c|}
\hline \multirow{2}{*}{ Gggregate } & \multicolumn{2}{|c|}{ Burned shale } & \multicolumn{2}{|c|}{ Expanded slag } \\
\hline & Coarse & Fine & Coarse & Fine \\
\hline \multicolumn{5}{|l|}{$\begin{array}{l}\text { Sieve analysis; aggregate passing } \\
\text { United States Standard Sieve: }\end{array}$} \\
\hline $1 / 2$ in 3 in & 100 & & 100 & \\
\hline No. 4 & $\begin{array}{l}88 \\
20\end{array}$ & 100 & $\begin{array}{l}98 \\
34\end{array}$ & 100 \\
\hline 8 & 5 & 97 & 13 & 96 \\
\hline do & 4 & 64 & 11 & 76 \\
\hline & 3 & 38 & 10 & 49 \\
\hline$=$ do & $\begin{array}{l}3 \\
3\end{array}$ & $\begin{array}{l}38 \\
25\end{array}$ & 10 & 30 \\
\hline ... do & 3 & 17 & 9 & 21 \\
\hline 200 & ${ }_{2}^{3}$ & 12 & 7 & \\
\hline A bsorption (surface dry) $48 \mathrm{hr}$ at $70^{\circ} \mathrm{F}$ & & & & \\
\hline $\begin{array}{l}\text { Bulk specific gravity (oven dry) }{ }^{\text {a }} \\
\text { Weight, loose, dry }\end{array}$ & $\begin{array}{r}15.8 \\
1.09 \\
37\end{array}$ & $\begin{array}{r}10.9 \\
1.54 \\
45\end{array}$ & $\begin{array}{r}36.8 \\
1.09 \\
40\end{array}$ & $\begin{array}{r}19.0 \\
1.46 \\
57\end{array}$ \\
\hline
\end{tabular}

a Absorption and bulk specific gravity determined by ASTM methods of test C $127-42$ and C $128-42$, respectively.

\section{Concrete}

The cement and lightweight aggregates of burned shale and expanded slag were proportioned by trial batches to produce concretes ranging from a low to a high cement content. Three mixtures of each were selected to produce a low-, medium-, and a high-strength concrete.

The burned-shale aggregate, in the original sacks, was completely inmersed in water for $48 \mathrm{hr}$ and then was allowed to drain, while still sacked, for $24 \mathrm{hr}$. The moisture content was determined, the amount of free water being included as mixing water in the proportioning of the materials. The expanded-slag aggregate was used in the dry condition as recommended by producers of this material.

The materials were proportioned by weight and the concrete was mixed in a standard $6-\mathrm{ft}^{3}$ rotary drum-type mixer. The air-entraining agent, when used, was introduced with the water and the time of mixing was in all cases about 5 minutes, as trial mixes indicated that this was the minimum interval needed to secure complete air entrainment.

All specimens were hand puddled. The forms were stripped at one day, and then the specimens were cured with wet burlap to an age of either 7 days or 28 days as required. They were then stored in the laboratory until tested.

Table 2 lists the data obtained on the fresh concrete, the weight and absorption of the dry concrete, and the compressive strengths of 6 - by 12-in. cylinders after aging 28 days. The weight of dry concrete was obtained after drying the specimens to constant weight in a chamber maintained at $122^{\circ} \mathrm{F}\left(50^{\circ} \mathrm{C}\right)$ and a lowered humidity (approximately 20 to 30 percent) obtained with pans of calcium chloride. The cement-voids ratio shown in the table is based on the absolute volume of all the ingredients, the voids including entrained air as well as all water other than that absorbed in the aggregate. Water absorption was determined on oven-dried specimens $\left(220^{\circ} \mathrm{F}\right)$ by immersing them in water at $70^{\circ} \mathrm{F}$ for $24 \mathrm{hr}$.

Water penetration due to capillarity was determined by placing three specimens of each concrete in a pan containing water $1 / 8$ to $1 / 4$ in. in depth. The specimens were 4 by 4 in. in cross section and about $12 \mathrm{in.} \mathrm{high.} \mathrm{Observations} \mathrm{were} \mathrm{made} \mathrm{at} 1 \mathrm{hr}$ and at 7 days to determine the height the water rose due to capillarity. The observed heights are given in table 2 . 
TABLE 2. Proportions of ingredients; density and absorption of concretes

\begin{tabular}{|c|c|c|c|c|c|c|}
\hline \multirow{2}{*}{ Cement content } & \multicolumn{6}{|c|}{ Aggregate } \\
\hline & \multicolumn{3}{|c|}{ Burned shale } & \multicolumn{3}{|c|}{ Expanded slag } \\
\hline Air-entraining agent, by weight of cement & .50 & .25 & None & .50 & .25 & None \\
\hline $\begin{array}{l}\text { Proportions, by loose volume, dry: } \\
\text { Portland ccment } \\
\text { Fine aggregate } \\
\text { Coarse aggregate }\end{array}$ & $\begin{array}{l}1.0 \\
6.2 \\
3.0\end{array}$ & $\begin{array}{l}1.0 \\
3.2 \\
2.0\end{array}$ & $\begin{array}{l}1.0 \\
1.4 \\
1.5\end{array}$ & $\begin{array}{l}1.0 \\
2.7 \\
2.2\end{array}$ & $\begin{array}{l}1.0 \\
1.5 \\
1.6\end{array}$ & $\begin{array}{l}1.0 \\
0.8 \\
1.2\end{array}$ \\
\hline Slump-1-1- & 2.5 & 4.3 & 6.4 & 4.0 & 6.0 & 5. 6 \\
\hline Cement voids a ratio by absolute volume & .122 & .247 & .611 & .174 & .303 & .652 \\
\hline Entrained air, by volume b & 20.8 & 13.9 & (०) & (24) & (18) & (0) \\
\hline $\begin{array}{l}\text { Weight of concrete: } \\
\text { Fresh } \\
\text { Dry }\end{array}$ & $\begin{array}{l}74.0 \\
60.3\end{array}$ & $\begin{array}{l}83.4 \\
71.4\end{array}$ & $\begin{array}{r}101.2 \\
88.2\end{array}$ & $\begin{array}{l}72.9 \\
65.1\end{array}$ & $\begin{array}{l}81.3 \\
72.8\end{array}$ & $\begin{array}{r}102.8 \\
96.2\end{array}$ \\
\hline $\begin{array}{l}\text { Compressive strength d at } 28 \text { days: } \\
\text { Cured } 7 \text { days wet, } 21 \text { days in air }\end{array}$ & 530 & 2,240 & 6,090 & 770 & 1,660 & 3,540 \\
\hline
\end{tabular}

s Voids=entrained air and mixing water.

b Values in parentheses are estimated.

Negligible.

d See table 3 for additional data.

\section{Description of specimens and test results}

\section{Compressive strength}

The specimens for compressive strength tests included 6 - by 12 -in. cylinders and some wallettes 8 by 30 by $30 \mathrm{in}$. The wallettes were used primarily to obtain values of shrinkage and were then tested in compression at the termination of those observations.
Values for the secant modulus of elasticity were obtained on cylinders wet-cured for 28 days by means of Tuckerman extensometers with a 6-in. gage length. The moduli were determined at stresses of 200,800 , and $2,000 \mathrm{lb} / \mathrm{in} .^{2}$, respectively, for the three grades of concrete. These values and the compressive strength values are given in table 3 .

TABLE 3. Compressive and flexural strengths of concrete specimens ${ }^{\mathrm{a}}$

\begin{tabular}{|c|c|c|c|c|c|c|}
\hline Cement content. & \multicolumn{3}{|c|}{ Burned shale } & \multicolumn{3}{|c|}{ Expanded slag } \\
\hline $\begin{array}{l}\text { Compressive strength: } \\
\text { Cylinders, 6- by } 12 \text {-in. } \\
\text { Age } 7 \text { days, wet-cured } \\
\text { Age } 28 \text { days, wet-cured } \\
\text { Age } 28 \text { days, } 7 \text { wet- and } 21 \text { air-cured. } \\
\text { Age } 2 \text { yr, } 7 \text { days wet-cured } \\
\text { Wallettes, } 30 \text { - by } 30 \text { - by } 8 \text {-in. }\end{array}$ & $\begin{array}{l}230 \\
480 \\
530 \\
650\end{array}$ & $\begin{array}{l}1,110 \\
1,730 \\
2,240 \\
2,590\end{array}$ & $\begin{array}{l}4,250 \\
5,720 \\
6,090 \\
5,850\end{array}$ & $\begin{array}{l}310 \\
590 \\
770 \\
860\end{array}$ & $\begin{array}{r}960 \\
1,510 \\
1,660 \\
1,570\end{array}$ & $\begin{array}{l}2,560 \\
3,380 \\
3,540 \\
3,100\end{array}$ \\
\hline Age 2 yr, 7 days wet-cured & 1,030 & 2,970 & 5,380 & 810 & 1,590 & 3,150 \\
\hline $\begin{array}{l}\text { Secant modulus of elasticity, } 6 \text { - by } 12 \text {-in. cylinder: } \\
\text { Age } 28 \text { days wet-cured: } \\
\text { At } 200 \text { lb/in. }\end{array}$ & 720,000 & & & 615,000 & & \\
\hline $\begin{array}{l}\text { At } 800 \mathrm{Ib} / \mathrm{in} .{ }^{2} \\
\text { At } 2000 \mathrm{lb} / \mathrm{in}{ }^{2}{ }^{2}\end{array}$ & & $1,240,000$ & $2,170,000$ & & $1,050,000$ & $2,000,000$ \\
\hline $\begin{array}{l}\text { Modulus of rupture in flexure of } 4 \text { - by } 4 \text {-in. bars: } \\
\text { Age } 28 \text { days, } 7 \text { wet- and } 21 \text { air-eured }\end{array}$ & 153 & 398 & 690 & 183 & 333 & 656 \\
\hline
\end{tabular}

s All values are the average for 3 specimens, except in the casc of wallettes, of which there was only one specimen each. 


\section{Flexural Strength}

Flexural strength tests were made on bars 4 by 4 in. in cross section and $30 \mathrm{in}$. long, at an age of 28 days. The bars were supported as a simple beam on a span of $24 \mathrm{in}$., and were loaded at the center with the screeded side of the concrete in compression. The computed values for the modulus of rupture are included in table 3 .

\section{Bond Strength to Reinforcement}

Reinforced concrete beams were made of the two strongest grades of each concrete with two makes of bar represented. Bond strengths after 28 days of wet curing were determined for lengths of embedment of 10,20 , and $30 \mathrm{in}$. by making and testing beams of different lengths. A sketch of the beams is shown in figure 1 .

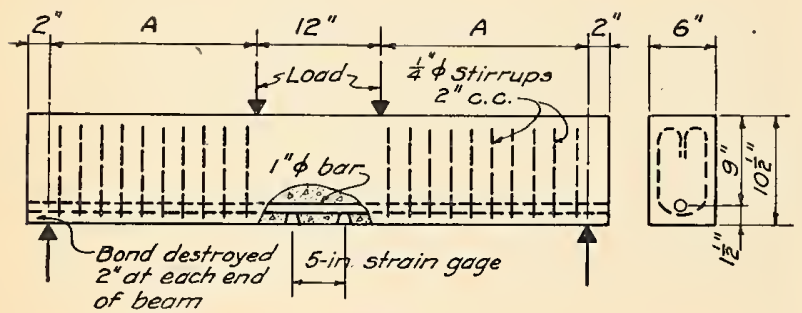

$A=$ length of embedment

FIGURE 1. Sketch of beams for bond strength tests.

The two bars represented are shown in figure 2 and have nominal diameters of $1 \mathrm{in}$. The deformations on bar $A$ are of the double helix pattern, reversing direction on the two faces of the bar. The deformations on bar $B$ are of the diamondpatterned type. The tensile properties determined for each bar are given in table 4 .

TABLE 4. Tensile properties of reinforcing bars

\begin{tabular}{|c|c|c|}
\hline & Bar $A$ & Bar $B$ \\
\hline $\begin{array}{l}\text { Cross-sectional area } \\
\text { Yield point- } \\
\text { Tensile strength } \\
\text { Elongation in } 8 \text { in }\end{array}$ & $\begin{array}{l}0.796 \\
60.400 \\
94,200 \\
18.8\end{array}$ & $\begin{array}{l}0.788 \\
52,000 \\
92.300 \\
23.1\end{array}$ \\
\hline
\end{tabular}

Most of the specimens exhibited bond failures, but in some the reinforcing bars yielded in tension. Where the latter occurred, bond stress values were based on the load at which yielding of the reinforcement occurred. Whittemore strain-gage readings on a 5 -in. gage length were made on the steel at the center of the beam through holes in the concrete. Slip at the ends of the bar was measured by using $0.0001-$ in. dial indicators fastened to two lugs embedded in the concrete, the dial stem being in contact with the end of the bar.

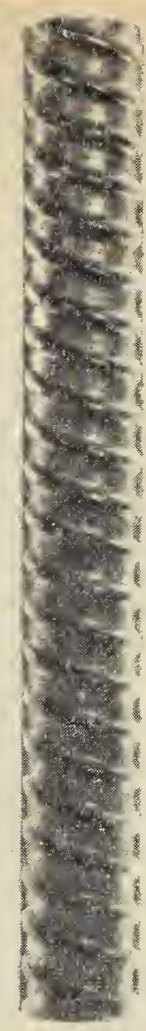

BAR" "A"

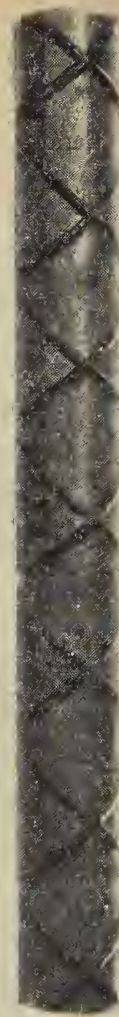

$B_{A R}^{17} B^{18}$

Figure 2. Types of bars for bond strength tests.

The computed bond stresses at an initial slip of 0.001 in., and the bond strength are given in table 5 .

TABLE 5. Bond strengths between concrete and reinforcement bars

\begin{tabular}{|c|c|c|c|c|}
\hline \multirow{3}{*}{ Cement content } & \multicolumn{4}{|c|}{ Aggregate } \\
\hline & \multicolumn{2}{|c|}{$\begin{array}{l}\text { Burned } \\
\text { shale. }\end{array}$} & \multicolumn{2}{|c|}{$\begin{array}{l}\text { Expanded } \\
\text { slag }\end{array}$} \\
\hline & 5.4 & 9.9 & 6.9 & 11.0 \\
\hline Compressive strengtb, 28 da wet........ lb/in. ${ }^{2}$ & 1,730 & 5,720 & 1,510 & 3,380 \\
\hline $\begin{array}{l}\text { Bond stress at } 0.001 \text { in. slip: } \\
\text { Bar A: } \\
\text { 10-in. embedment } \\
\quad 20 \text {-in. embedment } \\
\quad 30 \text {-in. embedment }\end{array}$ & $\begin{array}{l}320 \\
425 \\
420\end{array}$ & $\begin{array}{r}647 \\
600 \\
\text { a. } 520\end{array}$ & $\begin{array}{l}283 \\
320 \\
307\end{array}$ & $\begin{array}{r}440 \\
500 \\
\text { a } 520\end{array}$ \\
\hline 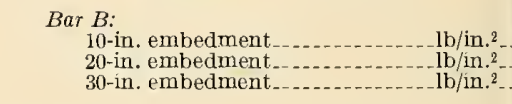 & $\begin{array}{l}182 \\
175 \\
157\end{array}$ & $\begin{array}{r}528 \\
425 \\
\text { a } 450\end{array}$ & $\begin{array}{l}212 \\
165 \\
180\end{array}$ & $\begin{array}{r}430 \\
340 \\
\text { а } 450\end{array}$ \\
\hline $\begin{array}{l}\text { Bond strength: } \\
\text { Bar } A \\
10 \text {-in. embedment } \\
\quad 20 \text {-in. embedment } \\
\quad 30 \text {-in. embedment }\end{array}$ & $\begin{array}{r}341 \\
506 \\
\text { a } 520\end{array}$ & $\begin{array}{ll} & 820 \\
\text { a } & 790 \\
\text { a } & 520\end{array}$ & $\begin{array}{l}318 \\
374 \\
328\end{array}$ & $\begin{array}{r}440 \\
610 \\
\text { a } 520\end{array}$ \\
\hline $\begin{array}{l}\text { Bar B: } \\
\quad \text { 10-in. embedment } \\
20 \text {-in. embedment } \\
30 \text {-in. embedment }\end{array}$ & $\begin{array}{l}310 \\
385 \\
267\end{array}$ & $\begin{array}{ll} & 619 \\
\text { a } & 680 \\
\text { a } & 450\end{array}$ & $\begin{array}{l}231 \\
221 \\
252\end{array}$ & $\begin{array}{r}530 \\
544 \\
\text { a } 450\end{array}$ \\
\hline
\end{tabular}

a Bond stress at tensile yielding of bars. 


\section{Heat-transfer properties}

Two types of specimens of each concrete were made for the heat-transfer tests, one for use in the shielded hot box and one to be tested by means of the guarded hot plate.

\section{(a) Shielded hot-box tests}

The walls for the shielded hot-box tests were 100 in. high, 8 in. thick, and 56 in. wide, and were tested at an age of 18 to 24 months, having been in storage in the laboratory for that length of time. They had been wet-cured for the first 7 days and exposed to the air for the remainder of the period.

The heat-transfer section of this bureau conducted the tests in a shielded hot-box apparatus designed for the purpose. During the test, heat flowed from the metering and shield boxes (which were heated electrically) through the wall to the cold box, which was cooled by a refrigerating machine. The electric energy supplied to the metering box and measured by a watt-hour meter was closely equivalent to the heat energy transferred through the portion of the wall covered by the metering box. The temperatures in the metering and shielded boxes were the same and were kept at $70^{\circ} \mathrm{F}$; the temperature in the cold box was kept at $0^{\circ} \mathrm{F}$, making the mean temperature approximately $35^{\circ}$ F. Air temperatures and surface temperatures on both sides of the wall were measured by means of thermocouples.

\section{(b) Guarded hot-plate tests}

The specimens for the guarded hot-plate tests were 8 by 8 in. in plan and about 1 in. in thickness.
They were cut from an 8-in. wall sample with one 8-in. dimension parallel to the thickness of the wall the other parallel to the height of the wall, and the 1-in. dimension parallel to the width of the wall.

The apparatus consisted of an electrically heated flat hot plate, $8 \mathrm{in}$. square, flanked on each side by a cold plate that was cooled by a flow of water at constant temperature. Two like specimens of each concrete were used, one being placed on each side of the hot plate and between it and the adjacent cold plate. The heat flowing through a central metering area 4 in. square was measured and the heat conductivity of the material com-. puted. The average mean temperature of the hot-plate specimens was approximately $68^{\circ} \mathrm{F}$. Immediately after testing, these specimens were dried for $24 \mathrm{hr}$ at $230^{\circ} \mathrm{F}$ in order to ascertain the moisture content of the concrete at the time of test.

\section{(c) Results of heat-transfer tests}

The results of the observations on heat-transfer tests are given in table 6 . The heat transmission is expressed in two ways: by the over-all heat transmittance, $U$, of the 8-in. wall, and by the thermal conductivity, $k$. Both heat-transfer coefficients were computed for each type of test to provide a comparison of values obtained by the two methods. It is believed that the moisture content of the large walls was considerably greater than that of the small specimens used in the hot-plate tests, and that the higher values obtained in the hot-box tests are due to this greater moisture content. The magnitude of this effect is indicated in table 6 by the two hot-plate tests made at different moisture contents on the burned-shale specimen leanest in cement.

TавLE 6. Heat-transfer coefficients

\begin{tabular}{|c|c|c|c|c|c|c|c|}
\hline Cement content & \multicolumn{4}{|c|}{ Burned shale } & \multicolumn{3}{|c|}{ Expanded slag } \\
\hline $\begin{array}{l}\text { Shielded hot-hox data: } \\
\text { Thickness of walls } \\
\text { Corrected thermal transmittance, }{ }^{\mathbf{a}} U_{-} \\
\text {Thermal conductivity, } k \text {. }\end{array}$ & & $\begin{array}{l}8.05 \\
0.26 \\
2.60\end{array}$ & $\begin{array}{l}8.06 \\
0.32 \\
3.44\end{array}$ & $\begin{array}{l}8.02 \\
0.41 \\
4.88\end{array}$ & $\begin{array}{l}8.00 \\
0.24 \\
2.41\end{array}$ & $\begin{array}{l}8.00 \\
0.30 \\
3.13\end{array}$ & $\begin{array}{l}8.00 \\
0.38 \\
4.34\end{array}$ \\
\hline Computed value of thermal transmittance for 8-in. wall, a $U$ & 0.20 & 0.24 & 0.24 & 0.29 & 0.19 & 0.23 & 0.32 \\
\hline
\end{tabular}

s $U=$ numher of Btil per hour transmitted through each square foot of specimen for each degree Fahrenheit difference in-temperature hetwecn the air on the two sides for a condition of still air on the warm side and a $15-\mathrm{mph}$ wind on the cold side.

$b k=$ numher of Btu per hour transmitted through each square foot of specimen for each degree Fahrenheit temperature difference in the material per inch t thickness.

\section{Thermal-expansion coefficients}

Six specimens, $1 \frac{1}{2}$ in. square and $9 \mathrm{in}$. long, were cut from specimens of each concrete. Data were obtained with a 6 -in. Tuckerman optical strain gage operating on specimens placed in a temperature-controlled box equipped with observation portholes. Readings were made at two extremes of temperature, $104^{\circ} \mathrm{F}\left(40^{\circ} \mathrm{C}\right)$ and $14^{\circ} \mathrm{F}\left(-10^{\circ} \mathrm{C}\right)$, a full cycle requiring $24 \mathrm{hr}$. Measurements were 


\begin{tabular}{|c|c|c|c|c|c|c|}
\hline \multirow[b]{3}{*}{ Cement content } & \multicolumn{6}{|c|}{ Aggregate } \\
\hline & \multicolumn{3}{|c|}{ Burned shale } & \multicolumn{3}{|c|}{ Expanded slag } \\
\hline & 3.0 & 5.4 & 9.9 & 4.4 & 6.9 & 11. 0 \\
\hline Coefficient of thermal expansion & 3.6 & 4.1 & 4.5 & 5.1 & 5. 5 & 6.2 \\
\hline $\begin{array}{l}\text { Shrinkage of 8-in. thick wallcttes in laboratory air: } \\
\text { At } 1 \text { yr.-- } \\
\text { At } 2 \text { yr. }\end{array}$ & $\begin{array}{l}-440 \\
-660\end{array}$ & $\begin{array}{l}-180 \\
-410\end{array}$ & $\begin{array}{l}a+160 \\
a+160\end{array}$ & $\begin{array}{l}-800 \\
-960\end{array}$ & $\begin{array}{r}-710 \\
-1,060\end{array}$ & $\begin{array}{l}-360 \\
-710\end{array}$ \\
\hline Changes in length $b$ during wetting and drying at $70^{\circ} \mathrm{F}$. & -270 & -500 & -600 & -400 & -630 & -970 \\
\hline
\end{tabular}

a The plus sign denotes an expansion of 0.000160 in./in.

$b$ Values signify shrinkage on drying cycle and are equal and opposite to expansion on wetting.

made for a number of cycles until the readings indicated no progressive changes in length. The temperature of the air surrounding the specimens was determined with calibrated copper-wire resistance thermometers and was controlled with a bimetal thermoregulator to $\pm 0.2 \mathrm{deg} \mathrm{F}$.

The coefficients of thermal expansion were determined for six like specimens, and the average for each concrete is reported in table 7 .

\section{Shrinkage}

Shrinkage was measured on wallettes 8 in. thick, $30 \mathrm{in}$. high, and $30 \mathrm{in}$. wide. Changes in the vertical direction beginning at an age of 1 week were obtained with a 20 -in. Whittemore strain gage. The specimens were stored in laboratory air, and measurements were made over a period of 2 years.

Values for change in length due to wetting and drying were also obtained. These measurements were made using a vertical comparator on specimens $1 \frac{1}{2}$ in. square and $7 \mathrm{in}$. long; the specimens were cut from larger pieces of the concrete. When 18 to 24 months old, they were fully wetted for a week in water at $70^{\circ} \mathrm{F}$, then dried to constant length at $70^{\circ} \mathrm{F}$ and 40 -percent relative humidity. They were then immersed for $48 \mathrm{hr}$. and again dried to constant length, several of these cycles being made. Measurements of changes in length were noted from the start, and it was found that there was but a slight change from cycle to cycle.
Values of shrinkage in laboratory air and those of change in length during wetting and drying are shown in table 7 .

\section{Rain Penetration}

The six specimens used for the water permeability tests, one of each mix, were about $51 \mathrm{in}$. high, 41 in. wide, and 8 in. thick. They were built on supporting channels with a 2 -in. mortar base containing a copper flashing projecting at the back. The surfaces were not finished in any way; the walls were tested at an age of 3 months in their original condition.

The water-permeability test is described in Building Materials and Structures Report BMS82, Water permeability of walls built of masonry units. ${ }^{1}$ The specimens were supported on metal skids, and when clamped in position, the exposed face formed one side of a pressure chamber. An air pressure of $10 \mathrm{lb} / \mathrm{ft}^{2}$ above atmospheric pressure was maintained in the chamber, and water from a perforated tube was sprayed near the top edge of the exposed face at the rate of $40 \mathrm{gal} / \mathrm{hr}$.

The arbitrary method of rating the performance as given in BMS82 was employed. All the walls were judged to be excellent because no visible water appeared above the flashings in 1 day, and in 5 days there was no leakage and less than 25 percent of damp wall area.

\footnotetext{
1 Obtainable from the Superintendent of Documents, Government Printing office, Washington $25, \mathrm{D}$. C., for 20 cents.
}

\section{Summary}

Specimens of lightweight-aggregate concretes made with burned shale or an expanded slag as the sole aggregates were tested for various physical properties.

Three grades of each concrete were made: a lean, an intermediate, and a rich concrete. The cement contents were $3.0,5.4$, and 9.9 sacks $/ \mathrm{yd}^{3}$, respectively, for the concretes with burned shale as the aggregat te and $4.4,6.9,11.0$ for the concretes made with expanded slag. An air-entraining agent was used with the portland cement in all but the richest mixtures of each type of concrete. The leanest mixtures with each aggregate had compressive strengths of 500 to $800 \mathrm{lb} / \mathrm{in} .^{2}$ and dry weights of 60 to $65 \mathrm{lb} / \mathrm{ft}^{3}$. Walls of this low-cement, high-void concrete possess heat-transfer properties suitable for insulation in some types of buildings. Hotplate test values of 1.8 and $1.9 \mathrm{Btu}$ in. $\mathrm{hr}^{-1} \mathrm{ft}^{-2}{ }^{\circ} \mathrm{F}^{-1}$ for thermal conductivity compare very favorably with values of 10 to 16 for ordinary dense concrete.

Heat transfer, compressive strength, and density all increased with increase in cement content, 
but thermal conductivity increased only to 3.0 and 3.4 for the dense mixtures, which is still a relatively low value for monolithic concrete.

Tests show that concrete with a compressive strength of $6,000 \mathrm{lb} /$ in. $^{2}$ can be made by using burned-shale aggregate; the expanded-slag mixture with a cement content of 11 sacks $/ \mathrm{yd}^{3} \mathrm{had}$ a compressive strength of $3,500 \mathrm{lb} / \mathrm{in}^{2}$. The ratio of compressive to transver'se strengths was about the same as for ordinary sand and gravel concrete, although more cement was required with the lightweight aggregates to obtain equivalent strengths. The modulus of elasticity was $2,170,000 \mathrm{lb} / \mathrm{in}^{2}{ }^{2}$ for a burnt shale aggregare concrete of $5,000-\mathrm{lb} / \mathrm{in} .^{2}$ compressive strength.

Bond strength between the concrete and the steel reinforcement was about the same as for ordinary dense aggregate concrete of the same compressive strength.

Coefficients of thermal expansion for the lightweight-aggregate concretes made with burned shale ranged from 3.6 to $4.5 \times 10^{-6} \mathrm{per}^{\circ} \mathrm{F}$, and from 5.1 to $6.2 \times 10^{-6}$ for those made with expanded slag. All of the mixtures showed normal shrinkage ranging from 0.02 to 0.10 percent, except the burnedshale concrete richest in cement. This exhibited an expansion of almost 0.02 percent when stored in laboratory air for a period of one year. Length changes during wetting and drying ranged from 270 to $600 \times 10^{-6}$ for the burned shale aggr'egate concretes and from 400 to $970 \times 10^{-6}$ for the expanded slag aggregate concretes; they were smallest for the lean concretes and largest for the rich concretes.

Resistance of walls to rain penetration was shown to be excellent.

The heat-transfer properties were determined by H. E. Robinson of the Bureau's Heat Transfer Section; the water permeability properties by C. C. Fishburn, of the Masonry Construction Section.

Washington, November 28, 1947. 




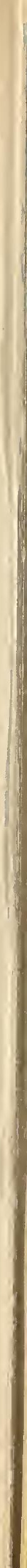




\section{BUILDING MATERIALS AND STRUCTURES REPORTS}

[Continued from cover page II]

BMS32 Structural Properties of Two Brick-Concrete-Block Wall Constructions and a Concrete-Block Wall Construction Sponsored by the National Concrete Masonry Association

BMS33

BMS34

Plastic Calking Materials.

Performance Test of Floor Coverings for Use in Low-Cost Housing: Part 1

Stability of Sheathing Papers as Determined by Accelerated Aging

Structural Properties of Wood-Frame Wall, Partition, Floor, and Roof Constructions With "Red Stripe" Lath Sponsored by The Weston Paper and Manufacturing Co

BMS37 Floors, Sponsored by Palisade Homes

BMS38 Structural Properties of Two "Dunstone" Wall Constructions Sponsored by the

W. E. Dunn Manufacturing Co
Structural Properties of a Wall Construction of "Pfeifer Units" Sponsored by the

BMS39 Wisconsin Units Co a W. $10 \%$

BMS40

Structural Properties of a Wall Construction of "Knap Concrete Wall Units" Sponsored by Knap America, Inc._...

BMS41 Effect of Heating and Cooling on the Permeability of Masony Walls

BMS43

BMS44

BMS45

BMS46

BMS47 Insulating Boards Sponsored by The Celotex Corporation . . .

Performance Test of Floor Coverings for Use in Low-Cost Housing: Part 2

Surface Treatment of Steel Prior to Painting

Air Infiltration Through Windows

Structural Properties of "Scott-Bilt" Prefabricated Sheet-Steel Constructions for Walls, Floors, and Roofs Sponsored by The Globe-Wernicke Co

Structural Properties of Prefabricated Wood-Frame Constructions for Walls, Partitions, and Floors Sponsored by American Houses, Inc .

BMS48 Structural Properties of "Precision-Built" Frame Wall and Partition Constructions Sponsored by the Homasote Co

BMS49 Metallic Roofing for Low-Cost House Construction

BMS50 Stability of Fiber Building Boards as Determined by Accelerated Aging--..- $10 \phi$

BMS51 Structural Properties of "Tilecrete Type A" Floor Construction Sponsored by the Tilecrete Co _.

BMS52 Effect of Ceiling Insulation Upon Summer Comfort

BMS53 Structural Properties of a Masonry Wall Construction of "Munlock Dry Wall Brick" Sponsored by the Munlock Engineering $\mathrm{Co}_{0} \ldots$

Effect of Soot on the Rating of an Oil-Fired Heating Boiler

Effects of Wetting and Drying on the Permeability of Masonry Walls._.........-. $10 \phi$

A Survey of Humidities in Residences

Roofing in the United States-Results of a Questionnaire-1

Strength of Soft-Soldered Joints in Copper Tubing-_...

Properties of Adhesives for Floor Coverings

Strength, Absorption, and Resistance to Laboratory Freezing and Thawing of Building Bricks Produced in the United States_._.

Structural Properties of Two Nonreinforced Monolithic Concrete Wall Constructions- $10 \phi$

Structural Properties of a Precast Joist Concrete Floor Construction Sponsored by the Portland Cement Association

Moisture Condensation in Building Walls

Solar Heating of Various Surfaces

Methods of Estimating Loads in Plumbing Systems

Structural Mroperties of "Mu-Steel" Prefabricated Sheet-Steel Constructions for Walls, Partitions, Floor, and Roofs, Sponsored by Herman A. Mugler...... 15ф

Performance Test for Floor Coverings for Use in Low-Cost Housing: Part 3

Stability of Fiber Sheathing Boards as Determined by Accelerated Aging

Asphalt-Prepared Roll Roofings and Shingles _. _

Fire Tests of Wood- and Metal-Framed Partitions

BMS70

BMS70

BMS71

BMS72

BMS73

BMS74 Construction Sponsored by the Homasote Co _.

Indentation Characteristics of Floor Coverings

Structural and Heat-Transfer Properties of "U. S. S. Panelbilt" Prefabricated SheetSteel Constructions for Walls, Partitions, and Roofs Sponsored by the Tennessee Coal, Iron \& Railroad Co.

BMS75

BMS76

BMS77

Survey of Roofing Materials in the North Central States

Effect of Outdoor Exposure on the Water Permeability of Masonry Walls

Properties and Performance of Fiber Tile Boards

Structural, Heat-Transfer, and Water-Permeability Properties of Five Earth-Wall Constructions

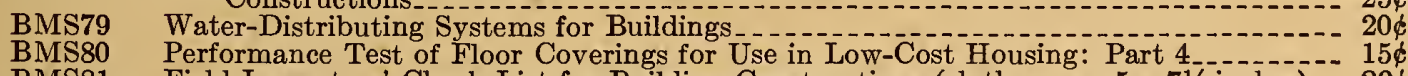

BMS81 Field Inspectors' Check List for Building Constructions (cloth cover, 5 x 71/2 inches) _. 20\&

*Out of print.

[List continued on cover page Iv] 


\section{BUILDING MATERIALS AND STRUCTURES REPORTS}

[Continued from cover page III]

BMS82

BMS83

BMS84

BMS85

BMS86

BMS87

BMS88

BMS89

BMS90

BMS91

BMS92

BMS93

BMS94

BMS95

BMS96

BMS97

BMS98

BMS99

BMS100

BMS101

BMS102

BMS103

BMS104

BMS105

BMS106

BMS107

BMS108

BMS109

BMS110

BMS111

BMS112

Out of print.
Water Permeability of Walls Built of Masonry Units

Strength of Sleeve Joints in Copper Tubing Made With Various Lead-Base Solders.$--10 \phi$
Survey of Roofing Materials in the South Central States.

Dimensional Changes of Floor Coverings With Changes in Relative Humidity and Temperature

Structural, Heat-Transfer, and Water-Permeability Properties of "Speedbrik" Wall Construction Sponsored by the General Shale Products Corporation

A Method for Developing Specifications for Building Construction-Report of Sub-
committee on Specifications of the Central Housing Committee on Research, committee on Specifications of the Central Housing Committee on Research,

Recommended Building Code Requirements for New Dwelling Construction With Special Reference to War Housing

Structural Properties of "Precision-Built, Jr." (Second Construction) Prefabricated Wood-Frame Wall Construction Sponsored by the Homasote Co Structural Properties of "PHC" Prefabricated Wood-Frame Constructions for Walls, Floors, and Roofs Sponsored by the PHC Housing Corporation A Glossary of Housing Terms. Fire-Resistance Classifications of Building Constructions. Accumulation of Moisture in Walls of Frame Construction During Winter Exposure-- $10 \phi$ Water Permeability and Weathering Resistance of Stucco-Faced, Gunite-Faced, and "Knap Concrete-Unit" Walls

Tests of Cement-Water Paints and Other Waterprefor $10 \varnothing$ Properties of a Porous Concrete of Cement and Uniform-Sized Gravel Experimental Dry-Wall Construction With Fiber Insulating Board. Physical Properties of Terrazzo Aggregates Structural and Heat-Transfer Properties of "Multiple Box-Girder Plywood Panels" for Walls, Floors, and Roofs Relative Slipperiness of Floor and Deck Surfaces Strength and Resistance to Corrosion of Ties for Cavity Walls Painting Steel Measurements of Heat Losses From Slab Floors Structural Properties of Prefabricated Plywood Lightweight Constructions for Walls, Partitions, Floors, and Roofs Sponsored by the Douglas Fir Plywood Association $25 \phi$

Paint Manual:-_..._. Laboratory Observations of Condensation in Wall Specimens Building Code Requirements for New Dwelling Construction Temperature Distribution in a Test Bungalow With Various Heating Devices... Strength of Houses: Application of Engineering Principles to Structural Design Paints for Exterior Masonry Walls Performance of a Coal-Fired Boiler Converted to Oil Properties of Some Lightweight-Aggregate Concretes With and Without an Airentraining Admixture. 